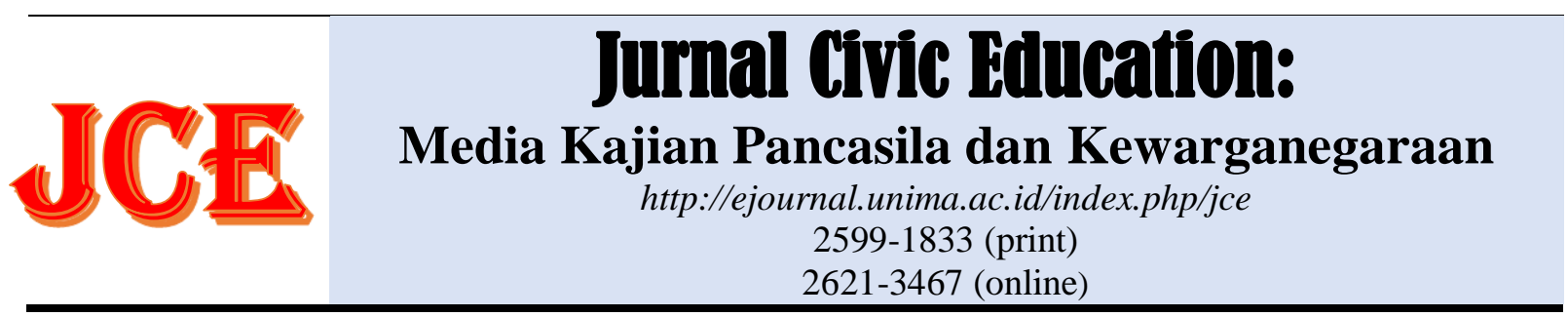

\title{
Eksistensi tenaga kerja indonesia dalam dimensi hukum hak asasi manusia
}

\author{
Joupy G .Z. Mambu ${ }^{\text {a, } 1^{*}}$ \\ a Program Studi Ilmu Hukum FIS Unima, Manado, Indonesia \\ 1 youpymambu@unima.ac.id \\ *korespondensi penulis
}

\begin{tabular}{ll}
\hline \multicolumn{2}{l}{ Informasi artikel } \\
\hline Sejarah artikel: \\
Diterima & $: 20-10-2019$ \\
Revisi & $: 10-11-2019$ \\
Dipublikasikan & $: 2-12-2019$ \\
\hline
\end{tabular}

Kata kunci:

Eksistensi

Tenaga kerja

Hak asasi manusia

\begin{abstract}
ABSTRAK
Penelitian ini merupakan penelitian hukum normatif dan mengkaji bahan hukum primer yaitu Undang-Undang Nomor 39 Tahun 1999 Tentang Hak Asasi Manusia, dan Undang-Undang Nomor 13 Tahun 2003 Tentang Ketenagakerjaan. Adapun masalah yang dibahas dalam penelitian ini yaitu hubungan kerja antara Perusahaan dengan Pekerja dalam hal ini Tenaga Kerja Indonesia yang sesuai dan menjunjung nilainilai Hak Asasi Manusia. Tujuan penelitian ini adalah untuk mengetahui hubungan antara perusahaan/majikan dengan pekerja/buruh yang menjunjung tinggi nilai-nilai hak asasi manusia. Hasil penelitian ini menunjukan bahwa intervensi pemerintah memang sudah banyak, antara lain Peraturan Perundang-Undangan yang dibuat, yang mengatur serta memberikan perlindungan bagi masyarakat, namun masih banyak peraturan yang belum terlaksana sebagaimana mestinya.

\section{ABSTRACT}

This research is a normative legal research and examines primary legal materials, namely Law Number 39 of 1999 concerning Human Rights, and Law Number 13 of 2003 concerning Labor. The problem discussed in this study is the employment relationship between the Company and Workers, in this case Indonesian Workers who are in line with and uphold the values of Human Rights. The purpose of this study was to determine the relationship between companies / employers and workers / laborers who uphold human rights values. The results of this study indicate that there are already many government interventions, including Laws and Regulations that are made, which regulate and provide protection for the community, but there are still many regulations that have not been implemented properly.
\end{abstract}

Keywords:

Existence

Labor

Human rights

Copyright $\odot 2019$ Joupy G.Z. Mambu. All Right Reserved

\section{Pendahuluan}

Manusia atau human dapat diartikan secara berbeda-beda menurut biologis, rohani, dan istilah kebudayaan, atau secara campuran. Secara biologis, manusia diklasifikasikam sebagai Homo sapiens (Bahasa Latin untuk manusia). Penggolongan manusia yang paling utama adalah berdasarkan jenis kelaminnya. Secara alamiah yakni biasa disebut laki-laki atau perempuan.

Menurut kodratnya, manusia pada hakekatnya tediri atas jiwa dan tubuh.jiwa terdiri atas akal, rasa dan kehendak, sedang tubuh terdiri atas unsur-unsur benda mati. Pada hakekatnya, manusia berkedudukan sebagai makhluk yang berdiri sendiri dan makhluk Tuhan (Notonagoro, 1975a).

Tenaga kerja sangat dibutuhkan untuk mengerjakan berbagai macam hal demi meningkatkan taraf hidupnya masingmasing, baik yang memerlukan tenaga kerja itu sendiri maupun orang yang mengerjakan pekerjaan, karena keduanya mempunyai hubungan timbal balik yaitu sama-sama saling membutuhkan. Manusia merupakan 
makhluk Tuhan yamg paling mulia diantara ciptaan-ciptaanNya yang lain karena memiliki akal budi, karena itu manusia memiliki haknya masing-masing, yang harus dihormati, dijaga, dan dilindungi, yang biasanya sering disebut sebagai Hak Asasi Manusia

Indonesia sebagai Negara yang sudah berkembang, yang memiliki penduduk yang berbeda-beda suku, agama, budaya, status sosial, dan lain-lain, memiliki kebutuhan ekonomi, pekerjaan, dan penghasilan yang berbeda-beda pula. Kurangnya lapangan pekerjaan dan tingginya angka pengangguran yang ada di Indonesia mengakibatkan banyak penduduk yang tidak mempunyai pekerjaan atau pengangguran, mengambil risiko untuk bekerja di luar negeri sebagai Tenaga Kerja Indonesia (TKI), demi memenuhi kebutuhan hidup mereka sendiri maupun keluarga mereka. Kesempatan yang sama bagi tenaga kerja untuk memperoleh pekerjaan dan hasil yang layak, yang pelaksanaannya dilakukan dengan tetap memperhatikan harkat dan martabat yang merupakan esensi atau hakikat hak asasi manusia hendaknya mendapat perlindungan hukum untuk keadilan serta pemerataan kesempatan kerja dan penyediaan tenaga kerja yang sesuai dengan kebutuhan.

Sebagai Negara yang sudah berkembang dan juga Negara yang penduduknya terpadat keempat di dunia, sehingga Indonesia menjadi Negara surplus tenaga kerja. Ada dua jenis migrasi yang paling mempengaruhi Indonesia, yaitu: Pertama adalah meningkatnya migrasi ke Negara-Negara maju, terutama yang tergabung dalam Organisasi Kerjasama Ekonomi dan Pembangunan di sini aliran dominan permanen dan sebagian besar terdiri dari tenaga kerja terampil. Kedua adalah gerakan, yang lebih dikenal sementara sebagian besar pekerja tidak terampil, misalnya ke Timur Tengah dan tempat lain di Asia.

Penempatan TKI di dalam dan luar negeri, merupakan program nasional dalam upaya meningkatkan kesejahteraan tenaga kerja dan keluarganya serta pengembangan kualitas sumber daya manusia.

Tenaga Kerja Indonesia (TKI) memiliki hak asasinya masing-masing karena Tenaga Keja Indonesia adalah manusia juga sehingga harus diperlakukan sebagai manusia dengan menghormati hak asasinya. Hak asasi manusia dimiliki oleh setiap orang berdasarkan fakta bahwa seseorang dilahirkan sebagai Manusia. Jadi, setiap manusia yang lahir padanya secara alami melekat hak asasi, dengan demikian setiap manusia mutlak melekat padanya hak asasi. Karena setiap manusia yang lahir padanya melekat hak asasi, maka manusia dimuka bumi ini mempunyai hak asasi begitu pula dengan Tenaga Kerja Indonesia (TKI). Tenaga Kerja Indonesia (TKI) juga memerlukan perlindungan hukum terhadap diri mereka masing-masing baik perlindungan fisik maupun, psikis, yaitu dengan perlindungan hak asasi serta harkat dan mertabat mereka masing-masing.

Menurut Anton Baker, Hak asasi manusia adalah hak yang dimiliki oleh manusia secara kodrat tanpa pengecualian dan keistimewaan bagi golongan, kelompok maupun tingkat sosial manusia tertentu.hak-hak tersebut mencakup antara lain hak atas kehidupan, keamanan, kebebasan berpendapat, dan merdeka dari segala bentuk penindasan yang wajib dijunjung tinggi, tidak saja oleh individu dari suatu Negara yang mengakui keberadaan dan menghargai HAM itu sendiri, namun harus juga dijamin oleh Negara tanpa ada pengecualiannya. Karena itu Tenaga Kerja Indonesia harus dilindungi oleh hukum karena sering terjadi pelanggaran pada TKI. Istilah Hak Asasi Manusia itu sendiri berarti hak tersebut ditemukan dalam hakikat kemanusiaan dan demi kemanusiaan (St Harum Pudjiarto, 1999).

Kebanyakan para tenaga kerja tidak terampil hukum, dan sebagian besar tebaga kerja adalah wanita. Wanita-wanita ini sebagian besar dipekerjakan sebagai pekerja rumah tangga. Menurut penelitian, lebih dari satu juta pekerja Indonesia wanita bekerja di Timur Tengah Dan Asia,

38| Jurnal Civic Education: Media Kajian Pancasila dan Kewarganegaraan 
sebaliknya para tenaga kerja laki-laki mendominasi arus ke Korea Selatan, Taiwan, dan Jepang.

Begitu banyaknya jumlah tenaga kerja Indonesia di dalam dan luar negeri, dan dari jumlah tersebut ada beberapa yang menimbulkan masalah yang termasuk dalam lingkup pelanggaran Hak Asasi Manusia. Isu Hak Asasi Manusia (HAM) sudah menjkadi agenda yang makin penting artinya dewasa ini, terutama paska berakhinya Perang Dunia II. Potret Hak Asasi Manusia (HAM) adalah suatu sejarah tentang penegakan kemerdekaan, kebebasan, keadilan, persamaan, perdamaian, persaudaraan, dan perlindungan. Penindasan (pelanggaran) terhadap HAM menempati fragmentasi historis, dengan fenomena yang berulangkali, bahwa rekaman sejarah terhadap nasib-nasib hak-hak asasi juga senantiasa menyuarakan bagian-bagian pembelaannya yang heroik atas musnahnya kemerdekaan itu sendiri bahkan Problema HAM telah berkembang sedemikian krusial, sehingga menjadi dilema global.

Deskripsi itu menunjukan mengenai sebagian realitas historis tentang perjanjian HAM. memang tidak sedikit di antara hakhak dasar manusia yang dilanggar oleh sesama manusia dan Negara. Negara dikategorikan sebagai pihak yang dipersalahkan ketika dalam posisinya sebagai organisasi warga bangsa, ternyata tidak selalu berhasil menjalankan kewajiban-kewajibannya (Lonto, Lolong, \& Pangalila, 2016).

Kurangnya lapangan pekerjaan yang ada di Indonesia merupakan salah satu faktor pendorong Jumlah Tenaga Kerja Indonesia ke berbagai Negara, yang dari tahun ke tahun terus mengalami peningkatan, dengan tujuan untuk memperbaiki taraf hidup mereka.

Bagi pemerintah Indonesia, arus TKI ke luar negeri adalah salah satu cara untuk mengatasi masalah pengangguran serta menjadi kontribusi sebagai pemasukan devisa Negara. Akan tetapi sejauh dapat diamati, dalam proses perekrutan dan penempatan TKI selalu menjadi pihak yang dirugikan. Belum lagi masalah yang berkaitan dengan biaya yang harus ditanggung oleh calon TKI sebelum ke luar negeri. Disamping itu, kepastian hukum untuk menjamin keselamatan TKI belum menjadi prioritas para TKI.

Dewasa ini tingginya migrasi tenaga kerja Indonesia ke luar negeri menimbulkan permasalahan, kebanyakan permasalahan itu muncul karena pelanggaran hak asasi tenaga kerja Indonesia di tempat ia bekerja. Baik secara fisik maupun psikis seseorang.

Pelanggaran HAM yang dialami tenaga kerja Indonesia ini bervariasi, mulai dari pelanggaran HAM ringan, berat, hingga sangat berat. pelanggaran HAM terhadap TKI, terutama TKW diantaranya hukuman cambuk yang diberlakukan pemerintah Malaysia kepada para pekerja migran. Penganiayaan juga sering dialami oleh TKI sehingga ia mengalami depresi.

Tragedi yang sama tak kalah memprihatinkan juga dialami oleh kurang lebih 400 TKI/TKW yang diperlakukan tidak manusiawi oleh para majikan di Arab Saudi. Kini mereka tertahan di barak penampungan yang mirip penjara di Riyadh Arab Saudi. Di antara korban-korban TKI di Arab Saudi itu adalah Shinta Marlina Reza (20) TKI asal Cianjur yang nasibnya terkatung-katung selama kurang lebih satu setengah tahun terakhir setelah disiksa oleh majikannya di Arab Saudi hingga cacat tangan kanan dan buta kedua matanya. Selain Shinta ada pula TKW yang melarikan diri dari tempat penampungan dan mengungkapkan adanya kasus penyekapan TKI tersebut. Demikian pula yang kini dialami oleh 54 orang TKI yang menghadapi ancaman hukuman mati di Malaysia. Belum lagi kasus-kasus TKI yang terjadi pada saat ia pulang ke daerah asal. Dalam perjalanannya sering menghadapi berbagai macan pelanggaran HAM yaitu penipuan, pemerasan, pembiusan, dan bahkan sampai pencelakaan dirinya..

Dari data tersebut, Indonesia mestinya melakukan suatu evaluasi yang menyeluruh dan melakukan pengusutan 
tuntas terhadap pelanggaran hak-hak warga Negara kita di negeri orang itu. Dengan persoalan-persoalan HAM yang telah diuraikan diatas, pelanggaran HAM terbanyak dialami oleh para kaum perempuan.

Ada beberapa hal penyebab yang menjadi asumsi terjadinya pelanggaran Hak Asasi Manusia:

1. Adanya persepsi tentang sesuatu dalam benak pelaku, bahkan seringkali yang mendasari tindak kekerasan ini bukan sesuatu yang dihadapi secara nyata. Hak ini dibuktikan dengan realitas di lapangan yang menunjukan bahwa pelaku telah melakukan tindakan kekerasan tersebut tanpa suatu alasan yang mendasar. Alasan yang disampaikan pelaku hamper selalu hanya didasarkan bahwa dirinya atau permainan bayang-bayang pikirannya saja, bahkan tidak jarang ia justru mengingkari telah berbuat jahat dan tidak terhormat. Lebih lagi jika pelaku menganggap tindakannya tidak dapat dikategorikan sebagai perbuatan melanggar HAM.

2. Hukum yang mengatur pelanggaran HAM pada TKI masih biasa. Seringkali hukum tidak berpihak pada kenyataan yang ada pada korban pelanggaran HAM itu sendiri. Ketidakberpihakan tersebut tidak hanya berkaitan dengan substansi hukum yang memperhatikan kepentingan si korban (Kontras, 2015).

Kurangnya pendidikan dan minimnya keterampilan pada diri rata-rata tenaga kerja Indonesia menimbulkan masalah-masalah pelanggaran HAM tersebut. Lemahnya perlindungan hukum bagi tenaga kerja Indonesia juga merupakan salah satu faktor terjadinya pelanggaran HAM .

Secara internal Indonesia harus segera memperbaiki sistem ketenagakerjaannya. Kalau memang TKI menjadi aset besar penghasilan devisa Negara, tentunya ada aspek-aspek yang harus diperhatikan bagi para TKI sebelum diberangkatkan ke luar negeri. Aspek mental, skill(keterampilan), bahkan sampai pada pengetahuan soal hak-haknya sebagai pekerja/buruh (Puspitasari, 2017).

\section{Metode}

"Jenis penelitian yang digunakan dalam penelitian ini adalah penelitian hukum normatif" (Soekanto \& Mamudji, 2001; Sunggono, 1997). Penelitian hukum normatif mengkaji hukum yang dikonsepkan sebagai norma atau kaidah yang berlaku. Norma hukum yang berlaku itu berupa norma hukum positif tertulis bentukan lembaga perundang-undangan (undang-undang dasar), kodifikasi, undangundang, peraturan pemerintah, sebagainya" (Muhammad, 2004).

"Peneitian tipe ini lazim disebut sebagai studi dogmatik atau yang dikenal dengan doctrinal research" (Sunggono, 1997) "Penelitian tipe doktrinal (doctrinal research) adalah mirip dengan tipe penelitian hukum normatif' (Sunggono, 1997). Dogmatik hukum bersifat teoritisrasional, sehingga pengungkapannya terikat pada metode yang didasarkan pada persyaratan logika dedukif. Disamping itu, maka dogmatik hukum memperhitungkan kecermatan, ketetapan dan kejelasan" (Soekanto \& Mamudji, 2001).

Menurut Abdulkadir Muhammad, "Penelitian hukum umumnya menggunakan analisis kualitatif, dengan alasan: (1) Data yng terkumpul berupa kalimat-kalimat pernyataan; (2) data yang terkumpul umumnya berupa informasi; (3) hubungan antara variabel tidak dapat diukur dengan angka...." (Muhammad, 2004)

Penelitian ini juga memusatkan perhatiannya pada hukum sebagai sistem peraturan-peraturan yang abstrak, hukum sebagai suatu lembaga yang benar-benar otonom, terlepas dari kaitannya dengan halhal diluar peraturan perundang-undangan. Menurut Bambang Sunggono, "Pemusatan perhatian yang demikian ini akan membawa kepada penggunaan metode normatif dalam menggarap hukum. Sesuai dengan cara pembahasan yang bersifat analitis, maka metode ini disebut sebagai normatif analitis."

Menurut Abdulkadir Muhammad. "Apabila penelitian itu menggunakan pendekatan normatif analitis substansi hukum (approach of legal content analysis),

40| Jurnal Civic Education: Media Kajian Pancasila dan Kewarganegaraan 
ada 3 (tiga) gradasi pendekatan normatif analisis yang dapat digunakan, yaitu: (a) Penjelajahan hukum (legal exploration); (b) Tinjauan hukum (legal review), dan (c) Analisis hukum atau analisis yuridis (legal analysis) adalah tingkatan tertinggi serta lebih komperhensif dalam kajian substansi hukum"(Muhammad, 2004).

Dengan demikian, analisis data dilakukan secara kualitatif, konperhensif, dan lengkap. Analisis kualitatif artinya menguraikan data secara bermutu dalam bentuk kalimat yang teratur, runtun, logis, tidak tumpang tindih, dan efektif. Konperhensif artinya analisis data dilakukan secara mendalam dari berbagai aspek sesuai dengan lingkup penelitian. Lengkap artinya tidak ada bagian yang terlewatkan atau terlupakan, semuanya masuk dalam analisis (Soekanto \& Mamudji, 2001).

\section{Hasil dan Pembahasan}

Hukum mengatur hubungan antara orang yang satu dengan yang lain, antara orang dengan masyarakat, antara masyarakat yang satu dengan yang lain. Jadi, antara orang yang satu dengan yang lain, dan seterusnya ada hubungan yang diatur oleh hukum. Sifat kehidupan masyarakat yang demikian adalah sesuai dengan ciri negara hukum.

Perkembangan dalam praktik negara hukum di negara-negara Barat ini telah mengubah pengertian asas legalitas yang semula diartikan sebagai pemerintahan berdasarkan atas UU (wetmatigheid van bertuur) menjadi pemerintahan berdasar atas hukum (rechtmatigheid van het bestuur) (Azhary, 1995).

Negara hukum menurut UUD Negara RI Tahun 1945 adalah negara hukum dalam arti luas atau negara hukum dalam arti materiil, artinya: "Negara bukan saja melindungi segenap bangsa Indonesia, tetapi juga harus memajukan kesejahteraan umum dan mencerdaskan kehidupan bangsa." Dengan landasan dan semangat negara hukum dalam arti meteriil itu setiap tindakan haruslah mempertimbangkan dua kepentingan ataupun landasan, yaitu landasan hukumnya (rechtmatigheid) dan kegunaannya (doelmatigheid).

Menurut Utrech, pengertian negara hukum berdasarkan dua asas pokok: (1) asas legalitas, (2) asas perlindungan kebebasan dan hak pokok manusia semua orang yang ada di wilayah negara, dalam hal kebebasan dan hak itu sesuai dengan kesejahteraan umum. Asas legalitas ialah asas bahwa semua tindakan alat-alat negara (termasuk setiap orang) harus didasarkan atas dan dibatasi oleh peraturan, yaitu "rule of law" (Utrecht \& Mohammad, 1962). Dalam literatur hukum khususnya hukum perdata, perbuatan-perbuatan hukum suatu subyek hukum dalam hubungannya dengan subyek hukum yang lain dikategorikan dalam hubungan hukum atau rechtsbetrekking.

Hubungan hukum (rechtsbetrekking) ialah hubungan antara dua atau lebih subyek hukum. Dalam hubungan hukum tersebut hak dan kewajiban pihak yang satu berhadapan dengan hak dan kewajiban pihak yang lain. Soeroso, mengatakan:

Semua hubungan di dalam masyarakat diatur oleh hukum. Misalnya, hubungan hukum yang diatur oleh hukum ialah Pasal 1457 KUH Perdata, tentang perikatan (verbintenis) yang timbul karena adanya suatu perjanjian (overeenkomst). Tiap-tiap hubungan hukum mempunyai dua segi, yaitu: (1) Bevoegdheid atau wewenang, yang disebut hak, dan (2) Plicht atau kewajiban (Soeroso, 1993).

$$
\text { Setiap hubungan hukum }
$$
(rechtsbetrekking) mempunyai dua segi, yaitu: (1) Bevoegdheid atau kewenangan yang disebut hak, dan (2) Plicht atau kewajiban.

Hubungan hukum (rechtsbetrekking) mempunyai tiga unsur, yaitu: (1) Adanya orang-orang yang hak/kewajibannya saling berhadapan; (2) Adanya obyek yang berlaku berdasarkan hak dan kewajiban tersebut; (3) Adanya hubungan antara pemilik hak dan pengemban kewajiban atau 
adanya hubungan atas obyek yang bersangkutan (Soeroso, 1993).

Di dalam UU tentang Ketenagakerjaan dikatakan: "Hubungan kerja adalah hubungan antara pengusaha dengan pekerja/buruh berdasarkan perjanjian kerja, yang mempunyai unsur pekerjaan, upah, dan perintah." "Hubungan kerja terjadi karena adanya perjanjian kerja antara pengusaha dan pekerja/buruh."

Apabila pengertian hubungan kerja dalam UU tentang Ketenagakerjaan dihubungkan dengan yang dikemukakan Soeroso tersebut di atas, maka jelas hubungan kerja antara perusahaan/majikan dengan pekerja/buruh adalah suatu hubungan hukum (rechtsbetrekking). Hubungan hukum (rechtsbetrekking) antara perusahaan/majikan dengan pekerja/buruh adalah suatu perikatan (verbintenis) yang timbul karena adanya suatu perjanjian (overeenkomst), karenanya hubungan hukum (rechtsbetrekking) antara perusahaan/majikan dengan pekerja/buruh mempunyai dua segi, yaitu bevoegdheid atau kewenangan yang disebut hak dan plicht atau kewajiban. Hak perusahaan/majikan berhadapan dengan kewajiban pihak pekerja/buruh sebaliknya hak pekerja/buruh berhadapan dengan kewajiban perusahaan/majikan.

Hubungan kerja antara perusahaan/majikan dengan pekerja/buruh memiliki unsur-unsur hubungan hukum (rechtsbetrekking) sebagai berikut: (1) Perusahaan/majikan dan pekerja/buruh memiliki hak dan kewajibannya; hak dan kewajiban masing-masing itu saling berhadapan; (2) Adanya obyek yaitu pekerjaan; dan (3) Adanya hubungan perusahaan/ majikan dan pekerja/buruh sebagai pemilik hak dan kewajiban atas obyek tersebut (pekerjaan).

Hubungan hukum (rechtsbetrekking) antara perusahaan/majikan dengan pekerja/buruh tercermin pada adanya hak dan kewajiban dari kedua belah pihak. Perusahaan/majikan mempunyai: (1) hak mendapatkan hasil pekerjaan dan hasil perintah (berupa barang atau jasa) dari pekerja/buruh, dan (2) kewajiban meberikan upah kepada pekerja/buruh; sedangkan pekerja/buruh mempunyai: (1) kewajiban melaksanaan pekerjaan dan perintah dari perusahaan/majikan, dan (2) berhak mendapatkan upah dari perusahaan/majikan.

Dari pengertian tersebut jelaslah bahwa hubungan kerja sebagai bentuk hubungan hukum lahir atau tercipta setelah adanya perjanjian kerja antara perusahaan/majikan dengan pekerja/buruh. Dengan demikian, jelaslah bahwa yang dapat disebutkan sebagai dasar pelaksanaan hubungan kerja antara perusahaan/majikan dengan pekerja/buruh adalah perjanjian kerja antara perusahaan/majikan dengan pekerja/buruh.

Hubungan

kerja antara perusahaan/majikan dengan pekerja/buruh adalah merupakan hubungan hukum yang bersegi dua (tweezijdige rechtsbetrekkingen) di mana kedua belah pihak dalam hal ini perusahaan/majikan dan pekerja/buruh (masing-masing) berwenang/berhak meminta sesuatu dari pihak lain; sebaliknya, kedua belah pihak dalam hal ini perusahaan/majikan dan pekerja/buruh (masing-masing) juga berkewajiban untuk memberikan sesuatu kepada pihak yang lain.

Berdasarkan uraian-uraian tersebut di atas jelaslah bahwa hubungan kerja antara perusahaan/majikan dengan pekerja/buruh bukan saja memenuhi prinsip-prinsip negara hukum karena perbuatan itu mempunyai landasan hukumnya (rechtmatigheid) tetapi jalas hubungan kerja antara perusahaan/majikan dengan pekerja/buruh tersebut juga memenuhi landasan kegunaannya (doelmatigheid) yaitu bahwa pada hakikatnya bahwa hubungan kerja antara pengusaha dengan pekerja/buruh dimaksudkan untuk meningkatkan kesejahteraan, kemakmuran baik perusahaan maupun pekerja/buruhnya.

Adanya hubungan hukum antara perusahaan/majikan dengan pekerja/buruh itu karena adanya perjanjian kerja. Karena adanya perjanjian kerja maka timbul peristiwa hukum (hubungan kerja), yaitu suatu perbuatan hukum yang akibatnya 
diatur oleh hukum (Soeroso, 1993). Apabila salah satu pihak, atau kedua belah pihak tidak mengindahkan kewajibannya, maka oleh hakim dapat dijatuhkan suatu sanksi hukum (Utrecht \& Mohammad, 1962).

Dapat dikatakan bahwa karena hubungan kerja antara perusahaan/majikan dengan pekerja/buruh adalah hubungan hukum, maka hubungan kerja antara perusahaan/majikan dengan pekerja/buruh tersebut harus berdasarkan hukum. Menurut Djumialdji, "hubungan kerja di sini harus suatu hubungan kerja yang Zakelijk, yaitu bahwa hubungan antara perusahaan/majikan dengan pekerja/buruh adalah hubungan yang formil. Lain halnya pada hubungan pembantu rumah tangga dengan majikannya yang lebih bersifat hubungan kekeluargaan" (Djumialdji, 2008)

Ketentuan hukum yang menjadi dasar pelaksanaan hubungan hukum dalam hal ini hubungan kerja antara perusahaan/majikan dengan pekerja/buruh ini dapat dikatakan sebagai sumber hukum atau dasar hukum hubungan kerja.

Menyimak pengertian hubungan kerja dalam UU tentang Kenagakerjaan yang mengatakan: "Hubungan kerja terjadi karena adanya perjanjian kerja antara perusahaan/majikan dan pekerja/buruh", maka dapat dikatakan sumber hukum atau dasar hukum pelaksanaan hubungan kerja yang paling utama adalah perjanjian kerja yang dibuat perusahaan/majikan dan pekerj/buruh. Hal ini juga sesuai dengan butir 8 (delapan) dari sumber hukum ketenagakerjaan yang dikemukakan Abdul Khakim tersebut di atas.

Untuk perjanjian kerja, berbagai istilah dijumpai dalam berbagai kepustakaan terdahulu. Perjanjian kerja dalam bahasa Belanda disebut Arbeidsoverenkoms. Wirjono Prodjodikoro, sesuai dengan Pasal 1601 a KUH Perdata menyebutnya dengan Persetujuan Perburuhan.

Berbicara tentang perjanjian kerja telah cukup jelas diatur di dalam UU
Tentang Ketenagakerjaan UU No. 13 Tahun 2003 terutama Pasal 50 sampai dengan Pasal 66, tetapi apabila ditelusuri lebih jauh lagi tentang sumber hukum perjanjian kerja, maka akan jelas bahwa sesungguhnya sumber hukum dari perjanjian kerja berawal pada KUH Perdata khususnya Buku III Perikatan, misalnya Pasal 1313 KUH Perdata menyatakan: "Suatu persetujuan adalah suatu perbuatan hukum di mana satu orang atau lebih mengikatkan diri terhadap satu orang lain atau lebih" (Soebekti, 2000) Kemudian Pasal 1320 KUH Perdata menyatakan: Supaya sahnya suatu perjanjian perlu dipenuhi empat syarat: (1) kesepakatan mereka yang mengikat dirinya; (2) kecakapan untuk membuat perjanjian (3) suatu hal tertentu; (4) suatu sebab yang halal. Sedangkan khusus untuk Perjanjian Kerja di dalam Pasal 1601 a KUH Perdata dinyatakan:

Perjanjian kerja adalah suatu perjanjian di mana pihak kesatu, yaitu buruh, mengikatkan diri untuk di bawah perintah yang lain, yaitu majikan, untuk suatu waktu tertentu melakukan pekerjaan dengan menerima upah.

Di dalam UU Tentang Ketenagakerjaan dinyatakan:

Perjanjian kerja dibuat atas dasar:

a. kesepakatan kedua belah pihak;

b. kemampuan atau kecakapan melakukan perbuatan hukum;

c. adanya pekerjaan yang diperjanjikan; dan d. pekerjaan yang diperjanjikan tidak bertentangan dengan ketertiban umum, kesusilaan, dan peraturan perundangundangan yang berlaku (Presiden Republik Indonesia, 2006).

Untuk sekedar mengulangi apa yang telah dikemukakan di atas bahwa yang dapat disebutkan sebagai dasar hukum atau sumber hukum yang utama dari pelaksanaan hubungan kerja antara perusahaan/majikan dengan pekerja/buruh adalah perjanjian kerja yang dibuat perusahaan/majikan dan pekerja/buruh. Pasal 1338 KUH Perdata menyatakan: "Semua persetujuan yang dibuat sesuai dengan undang-undang berlaku sebagai 
undang-undang bagi mereka yang membuatnya" (Soebekti, 2000). Dengan demikian dapat dikatakan bahwa semua perjanjian kerja antara perusahaan/majikan dengan pekerja/buruh yang sesuai dengan peraturan perundang-undangan adalah berlaku sebagai UU bagi perusahaan/majikan dan pekerja/buruh.

Secara runtun dapat dikemukakan, perjanjian kerja antara perusahaan/majikan dengan pekerja/buruh adalah suatu perbuatan hukum di mana pihak pekerja/buruh mengikatkan diri terhadap perusahaan/majikan atau sebaliknya pihak perusahaan mengikatkan diri terhadap pekerja/buruh sesuai perjanjian kerja. Supaya sahnya suatu perjanjian kerja antara perusahaan dengan pekerja/buruh tersebut perlu dipenuhi empat syarat, yaitu: (1) kesepakatan kedua belah pihak;

kemampuan atau kecakapan melakukan perbuatan hukum; (3) adanya pekerjaan yang diperjanjikan; dan (4) pekerjaan yang diperjanjikan antara perusahaan/majikan dengan pekerja/buruh adalah suatu yang halal.

Dengan demikian, apabila mengadakan suatu perjanjian maka apa yang dikehendaki pihak yang satu harus dikehendaki pihak yang lain. Apabila mengacu pada ketentuan Pasal 1 UU Tentang Ketenagakerjaan yang menyatakan: "Hubungan kerja adalah hubungan antara pengusaha dengan pekerja/buruh berdasarkan perjanjian kerja, yang mempunyai unsur pekerjaan, upah, dan perintah" (Presiden Republik Indonesia, 2006), maka pihak pekerja menerima atau setuju terhadap pekerjaan, upah dan setuju untuk diperintah oleh pihak pengusaha; sedangkan sebaliknya pihak pengusaha menerima pekerja tersebut untuk dipekerjakan. Pihak pekerja/buruh harus dalam keadaan secara bebas artinya tidak misalnya dalam keadaan tertekan atau ketakutan karena diancam untuk menerima atau menyetujui pekerjaan, upah, dan diperintah oleh pihak pengusaha; demikian sebaliknya.

Di dalam Pasal 52 ayat (2) UU Tentang Ketenagakerjaan dinyatakan:
"Perjanjian kerja yang dibuat oleh pihak yang bertentangan dengan ketentuan sebagaimana dimaksud dalam ayat (1) huruf a dan b dapat dibatalkan." Ketentuan huruf a dan b yaitu "kesepakatan kedua belah pihak" dan "kemampuan atau kecakapan melakukan perbuatan hukum".

Jadi, apabila pada waktu pembuatan perjanjian kerja itu, ada kekurangan terhadap syarat yang subyektif, maka perjanjian itu bukannya batal demi hukum, tetapi dapat dimintakan pembatalan oleh salah satu pihak; salah satu pihak yang dimaksudkan di sini ialah pihak yang pada waktu memberikan persetujuan terhadap perjanjian kerja itu dalam keadaan tidak bebas.

Kemampuan atau kecakapan melakukan perbuatan hukum ini merupakan syarat kedua dari sahnya suatu perjanjian kerja yang dirumuskan di dalam Pasal 52 ayat (1) UU Tentang Ketenagakerjaan. Seperti dikemukakan di atas menurut Subekti syarat kedua sahnya suatu perjanjian dinamakan syarat subyektif, karena mengenai orang-orangnya atau subyeknya yang mengadakan perjanjian (Subekti, 1987).

Di dalam UU Tentang Ketenagakerjaan dikatakan: "Yang dimaksud dengan kemampuan atau kecakapan adalah para pihak yang mampu atau cakap menurut hukum untuk membuat perjanjian. Beberapa golongan orang dinyatakan "tidak cakap" untuk melakukan sendiri perbuatan-perbuatan hukum, ialah: orang yang dibawah umur, orang yang berada di bawah pengawasan (curatele). Orang yang ditaruh di bawah pengampuan menurut hukum tidak dapat berbuat secara bebas dengan harta kekayaannya (Subekti, 1987). Selain itu seseorang dikatakan cakap membuat perjanjian jika orang tersebut tidak terganggu jawanya.

Kemampuan artinya kesanggupan; kecakapan; kekuatan. Kecakapan artinya kemampuan; kesanggupan; kepandaian atau kemahiran mengerjakan sesuatu (Poerwadarminta, 2002). Orang yang membuat perjanjian harus cakap menurut hukum. Pada asasnya setiap orang yang

44| Jurnal Civic Education: Media Kajian Pancasila dan Kewarganegaraan 
sudah dewasa atau akilbaliq dan sehat pikirannya adalah cakap menurut hukum. Dari sudut rasa keadilan, perlulah bahwa orang yang membuat suatu perjanjian dan nantinya akan terikat oleh perjanjian itu mempunyai cukup kemampuan atau kecakapan sehingga dapat menginsyafi benar-benar akan tanggung jawab yang dipikulnya dengan perbuatannya itu. Sedangkan dari sudut ketertiban hukum, karena seorang yang membuat suatu perjanjian itu berarti mempertaruhkan kekayaannya, maka orang tersebut haruslah seorang yang sungguh-sungguh berhak secara bebas berbuat dengan harta kekayaannya. Orang yang tidak sehat pikirannya tidak mampu menginsyafi tanggung jawab yang akan dipikulnya dengan mengadakan suatu perjanjian (Subekti, 1987).

Berdasarkan uraian di atas, maka dapatlah dikatakan bahwa perusahaan/majikan maupun pekerja/buruh dalam mengadakan perjanjian kerja disyaratkan harus memiliki kemampuan atau kecakapan hukum sehingga dapat menginsyafi benar-benar akan tanggung jawab yang dipikulnya dengan mengadakan perjanjian kerja itu. Sedangkan dari sudut ketertiban hukum, karena perusahaan/majikan yang membuat suatu perjanjian kerja itu berarti mempertaruhkan kekayaannya; sedangkan pekerja/buruh yang membuat suatu perjanjian kerja itu berarti mempertaruhkan tenaga, daya, potensinya, maka perusahaan/majikan dan pekerja/buruh tersebut haruslah orangorang yang sungguh-sungguh berhak secara bebas berbuat terhadap apa saja yang dimilikinya tersebut.

Syarat kemampuan atau kecakapan melakukan perbuatan hukum ini sama halnya dengan syarat pada unsur kesepakatan; apabila pada waktu pembuatan perjanjian, ada kekurangan mengenai unsur subyektif, maka perjanjian itu bukannya batal demi hukum, tetapi dapat dimintakan pembatalan oleh salah satu pihak; dan salah satu pihak yang dimaksudkan di sini ialah pihak yang pada waktu memberikan persetujuan terhadap perjanjian itu belum atau tidak memiliki kemampuan atau kecakapan melakukan perbuatan hukum.

Hak asasi manusia adalah seperangat hak yang melekat pada hakikat dan keberadaan manusia sebagai makhluk Tuhan Yang Maha Esa dan merupakan anugerah-Nya yang wajib dihormati, dijunjung tinggi, dan dilindungi oleh Negara, hukum, dan Pemerintah, dan setiap orang demi kehormatan serta perlindungan harkat dan marabat manusia (Lonto et al., 2016). Menurut Notonagoro, Hakikat manusia adalah monopluralis, menurut kodratnya manusia pada hakikatnya terdiri atas jiwa dan tubuh, jiwa dan tubuh merupakan dua hal yang tidak dapat dipisahkan, aliran ini disebut monodualisme; menurut kodratnya manusia pada hakikatnya bersifat sebagai mahluk individu dan mahluk sosial, keduanya merupakan satu kesatuan yang bulat, aliran ini dinamakan mono-dualisme; menurut kodratnya manusia berkedudukan sebagai mahluk berdiri sendiri dan mahluk Tuhan, aliran ini disebut mono-dualisme. Jika seluruhnya dijadikan satu ... maka aliran ini dinamakan mono pluralis. Karena itu manusia adalah mahluk mono dualis atau mono pluralis (Notonagoro, 1975b).

Menurut kodratnya, manusia pada hakekatnya terdiri atas jiwa dan tubuh, dan bersifat sebagai makhluk individu dan makhluk sosial. Pada hakekatnya tidak ada orang yang seratus persen bersifat individualistik artinya hanya memperhatikan kepentingan dirinya sendiri saja, dan sama sekali tidak memperhatikan kepentingan orang lain (Sunoto, 2003).

Manusia Indonesia adalah manusia yang berunsurkan jiwa dan raga, manusia yang mempunyai sifat individu dan sosial dan merupakan makhluk Tuhan yang memiliki akal budi, yang masing-masing memilki harkat dan martabat.

Harkat adalah taraf, mutu, nilai, dan kemuliaan dari diri manusia, sedangkan Martabat adalah tingkat harkat manusia atau harga diri manusia. Harkat dan 
martabat dari diri pekerja/buruh haruslah dihormati, dan dijunjung tinggi oleh perusahaan/majikan sebagai penghormatan terhadap hak asasi manusia, karena pekerja/buruh adalah manusia.

Dalam kaitannya dengan hubungan kerja antara Perusahaan/Majikan dengan pekerja/buruh hendaknya sesuai dan/atau menjunjung tinggi nilai-nilai manusia yang monopluralis tersebut.

Dalam kaitannya dengan hubungan kerja antara Perusahaan/Majikan dengan pekerja/buruh hendaknya sesuai dan/atau menjunjung tinggi nilai-nilai baik harkat maupun martabat manusia.

Di dalam pelaksanaan hubungan kerja yang sesuai dan menjunjung nilai-nilai hak asasi manusia, maka dibutuhkan perlindungan untuk melindungi para pekerja/buruh, dalam hal ini tenaga kerja Indonesia (TKI) dengan tujuan untuk menjamin berlangsungnya sistem hubungan kerja secara harmonis tanpa disertai tekanan dari pihak yang kuat terhadap pihak yang lemah. Untuk itu perusahaan/majikan wajib melaksanakan ketentuan perlindungan tenaga kerja tersebut sesuai dengan peraturan perundang-undangan yang berlaku.

Perlindungan Hak Asasi Manusia (HAM) merupakan istilah yang sangat luas maknanya. Undang-undang tentang Hak Asasi Manusia tidak memberikan penafsiran yang lengkap terhadap istilah perlindungan tersebut. Pada dasarnya terdapat pengakuan yang tegas dalam Undang-Undang tentang HAM atas penggunaan upaya hukum nasional dan forum internasional atas semua pelanggaran HAM. Salah satu media dari upaya hukum tersebut adalah pengadilan HAM.

Setiap Tenaga Kerja Indonesia di dalam maupun luar negeri mempunyai hak untuk memperoleh perlindungan sesuai dengan peraturan perundang-undangan. Disamping pemerintah, pelaksana penempatan Tenaga Kerja Indonesia (TKI) swasta juga bertanggung jawab untuk memberikan perlindungan kepada TKI sesuai dengan peraturan perundangundangan dan perjanjian penempatan.
Politik hukum sebagai arah sistem hukum nasional harus memberikan arahan bagaimana arahan kebijakan tersebut dilaksanakan oleh para penyelenggara pemerintahan dari pusat dan sampai satuan pemerintah yang lebih rendah. Kebutuhan akan peran pemerintah lokal tersebut diperkuat oleh suatu pemahaman mengenai paradigma Negara kesejahteraan, yang menghendaki campur tangan Negara disegala bidang kehidupan Masyarakat.

Setiap tenaga kerja mempunyai hak kesempatan yang sama untuk memilih, mendapatkan, atau pindah pekerjaan dan memperoleh penghasilan yang layak di dalam atau luar negeri. Penempatan dan perlindungan Tenaga Kerja Indonesia berasaskan keterpaduan, persamaan hak, demokrasi, keadilan gender, anti diskriminasi serta anti perdagangan manusia.

Tenaga Kerja Indonesia di dalam dan luar negeri berhak mendapatkan jaminan kesempatan dan kesamaan hak-hak normatif. Serta, kesejahteraan atas dirinya dan keluarga dalam perlindungan kepastian hukum dan hak asasi manusia nasional dan internasional.

Tenaga Kerja Indonesia didalam dan diluar negeri pada dasarnya sudah melekat hak-hak yang sudah diatur oleh UndangUndang dan sudah dilindungi oleh pemerintah, adanya sistem perlindungan terhadap TKI merupakan hal yang diharapkan oleh banyak pihak, terutama TKI itu sendiri yang selama ini menghadapi berbagai masalah.

Secara keseluruhan, hubungan kerja yang menjunjung nilai-nilai hak asasi manusia adalah hubungan kerja yang memperhatikan dan menghormati hak-hak akan masing-masing pihak yaitu antara perusahaan/majikan dan pekerja/buruh, agar tidak terjadi hal-hal yang tidak diinginkan oleh masing-masing pihak. Karena itu hak dan kewajiban dari perusahaan/majikan dan pekerja/buruh harus berjalan bersama-sama dan seimbang antara hak dan kewajiban sehingga tidak akan terjadi pelanggaran harkat dan 
martabat masing-masing pihak yang terkait dalam hubungan kerja ini.

\section{Simpulan}

$\begin{array}{lcr}\text { Hubungan } & \text { kerja } & \begin{array}{r}\text { antara } \\ \text { dengan }\end{array} \\ \text { Perusahaan/majikan } & & \text { suatu } \\ \text { perusahaan/Buruh } & \text { merupakan } \\ \text { hubungan hukum } & \text { (rechtsbetrekking), }\end{array}$ dimana hukum mengatur hubungan antara orang yang satu dengan yang lain, antara orang dengan masyarakat, antara masyarakat satu dengan yang lain, dan seterusnya ada hubungan yang diatur oleh hukum.

2. Sahnya hubungan kerja antara Perusahaan/Majikan dengan Pekerja/Buruh terjadi apabila dipenuhinya 4 syarat sahnya perjanjian yaitu: (1) Kesepakatan kedua belah pihak; (2) Kemampuan atau kecakapan melakukan perbuatan hukum; (3) Adanya pekerjaan yang diperjanjikan; (4) Pekerjaan yang diperjanjikan Perusahaan/Majikan dengan Pekerja/Buruh adalah suatu yang halal.

\section{Referensi}

Azhary, H. (1995). Negara hukum Indonesia suatu analisis yuridis normatif tentang unsur-unsurnya. Jakarta: UI Press.

Djumialdji, F. X. (2008). Perjanjian kerja. Jakarta: Bumi Aksara.

Kontras. (2015). Menemukan Hak Atas Tanah Pada Standar Hak-Hak Asasi Manusia Di Indonesia. Jakarta: Komisi untuk Orang Hilang dan Korban Tindak Kekerasan (KontraS).

Lonto, A. L., Lolong, W. R. J., \& Pangalila, T. (2016). Hukum Hak Asasi Manusia. Yogyakarta: Penerbit Ombak. Retrieved from https://books.google.co.id/books?id=u F5JnQAACAAJ
Muhammad, A. (2004). Hukum dan penelitian hukum. Citra Aditya Bakti, Bandung.

Notonagoro. (1975a). Pancasila secara ilmiah populer. Pancasila Secara Ilmiah Populer. Jakarta: Pantjuran.

Notonagoro. (1975b). Pancasila Secara Ilmiah Populer. Jakarta: Pantjuran.

Poerwadarminta, W. J. S. (2002). Kamus besar bahasa Indonesia. Jakarta: Balai Pustaka.

Presiden Republik Indonesia. (2006). Undang-Undang Republik Indonesia Nomor 13 Tahun 2003 tentang Ketenagakerjaan.

Puspitasari, W. I. (2017). Faktor-faktor yang Mempengaruhi Migrasi Tenaga Kerja Ke Luar Negeri Berdasarkan Provinsi di Indonesia. Jurnal Ilmu Ekonomi Terapan, 2(1).

Soebekti, R. (2000). Kitab undang undang hukum perdata: burgerlijk wetboek. Jakarta: Rineka Cipta.

Soekanto, S., \& Mamudji, S. (2001). Penelitian hukum normatif: Suatu tinjauan singkat. RajaGrafindo Persada.

Soeroso, R. (1993). Pengantar Ilmu Hukum, Cet. Ke-1, Jakarta: Sinar Grafika.

St Harum Pudjiarto, R. S. (1999). Hak asasi manusia. Universitas Atma Jaya Yogyakarta.

Subekti, R. (1987). Hukum perjanjian. Jakarta: Intermasa.

Sunggono, B. (1997). Metodologi penelitian hukum: suatu pengantar. PT RajaGrafindo Persada.

Sunoto. (2003). Mengenal Filsafat Pancasila. Yogyakarta: Hanindita Graha Widya.

Utrecht, E., \& Mohammad, S. D. (1962). Pengantar dalam Hukum Indonesia, Cet. Ichtiar, Jakarta, 23. 